\title{
Pengaruh Variasi Temperatur Tuang pada Pengecoran Daur Ulang Al-Si terhadap Struktur Mikro dan Kekerasan dengan Pola Styrofoam
}

Helmy Purwanto ${ }^{a^{*}}$, Darmanto $^{b}$, Nur Kholis ${ }^{c}$, Wahid Mufidind

a *Program Studi Teknik Mesin, Fakultas Teknik, Universitas Wahid Hasyim, Jl. Menoreh Tengah X/22, Semarang, Indonesia, Telp.(024) 8505680/Fax. (024) 8505681

e-mail: *helmypurwanto@unwahas.ac.id

b,c,d Program Studi Teknik Mesin, Fakultas Teknik, Universitas Wahid Hasyim

J1. Menoreh Tengah X/22, Semarang, Indonesia, Telp.(024) 8505680/Fax. (024) 8505681

e-mail: darmanto@unwahas.ac.id; nurkholis@unwahas.ac.id; wachid.mufidin@gmail.com

Kata kunci:

Pengecoran

$\mathrm{Al}$, Struktur

Mikro,

Kekerasan

Keyword:

Al Casting, Micro

Structure, Hardness

\section{ABSTRAK}

Penelitian ini bertujuan mengetahui pengaruh temperatur tuang pada pengecoran daur ulang Al-Si terhadap struktur mikro dan kekerasan dengan menggunakan pola Styrofoam. Material aluminium dari velg bekas diplih sebagai bahan utama dalam penelitian ini. Parameter yang digunakan_dalam pengecoran adalah temperatur tuang dengan variasi 660,710 , dan $760^{\circ} \mathrm{C}$. Pengamatan struktur mikro dan pengukuran SDAS menggunakan mikroskop optic dan image analysis software. Pengujian kekerasan dilakukan untuk mengetahui sifat mekanis material. Hasil pengujian menunjukkan SDAS semakin kasar atau meningkat $56 \%$ pada temperatur tuang $760^{\circ} \mathrm{C}$ sehingga mengalami peningkatan kekuatan mekanik sebesar $2.59 \%$.

\section{ABSTRACT}

This study aims to determine the effect of pouring temperature on recycled Al-Si casting on microstructure and hardness using a styrofoam pattern. Aluminum material from used velg was chosen as the main material in this study. The parameters used in the casting are pouring temperatures which are varied of $660,710,7600$ C. Microstructure observation and SDAS measurement using optical metallography and image analysis software. Hardness testing is carried out to determine the mechanical properties of the material. The test results showed that the SDAS was getting coarser or increased by $56 \%$ at a pouring temperature of $7600 \mathrm{C}$ so that the mechanical strength increased by $2.59 \%$.

\section{PENDAHULUAN}

Logam aluminium merupakan bahan teknik yang paling menjanjikan setelah baja untuk masyarakat modern karena banyak digunakan untuk pengemasan makanan, transportasi, konstruksi, otomotif, dan lainnya[1][2]. Aluminium mempunyai karakteristik ringan, ketahanan korosi yang tinggi, dan memiliki sifat kemampuan untuk pengecoran yang baik[3]. Saat ini, permintaan logam aluminium di seluruh dunia semakin tinggi sehingga menimbulkan permasalahan pada ketersediaan bahan baku biji aluminium. Di sisi lain, limbah aluminium tersedia cukup banyak. Limbah aluminium berasal dari limbah industri maupun komponen berbahan baku aluminium yang umur pakainya telah habis. Salah satu cara mengurangi jumlah limbah dapat dilakukan dengan mendaur ulang limbah aluminium. Metode daur ulang yang dapat dilakukan adalah dengan memanfaatkan limbah aluminium untuk proses pengecoran[4].

Pengecoran merupakan proses manufaktur dengan cara menuangkan logam cair pada pola cetakan pengecoran untuk menghasilkan suatu benda yang mendekati produk asli[2]. Pengecoran secara garis besar dibagi dua, yaitu pengecoran dengan cetakan logam dan pengecoran dengan cetakan pasir. Pengecoran dengan cetakan logam, cetakannya terbuat dari logam dengan dibuat rongga sesuai produk 
yang dihasilkan. Sementara itu, pengecoran dengan cetakan pasir memerlukan pola sesuai produk yang dihasilkan. Salah satu penggecoran dengan cetakan pasir adalah metode lost foam casting dengan pola styrofoam [5]. Lost Foam Casting (LFC) merupakan salah satu metode pengecoran dengan menggunakan pola polystyrene foam. Metode LFC adalah desain pola dari styrofoam beserta sistem salurannya yang ditanam pada pasir silica, kemudian dipadatkan. Majid karimian [6] telah melakukan pengecoran LFC menggunakan material Al-Si dengan parameter temperatur tuang 660, 680, 700, 720, $760^{\circ} \mathrm{C}$. Saluran masuk pada cetakan pasir juga divariasikan untuk mendapatkan bentuk replika dan kekasaran permukaan yang halus. Hasil penelitian menunjukkan bahwa desain lubang masuk dan suhu yang tinggi mempunyai pengaruh yang sangat signifikan, bentuk replika yang sedikit memiliki porositas dan kekasaran yang lebih halus[6]. Metode pengecoran secara konvensional dan LFC pada material $\mathrm{Al} / \mathrm{Mg}$ terhadap struktur mikro dan kekerasan juga telah diteliti. Penelitian tersebut menunjukkan terbentuknya lapisan Metal Matrix Composites (MMCs) baru, yaitu $\mathrm{Al}_{3} \mathrm{Mg}_{2}, \mathrm{Al}_{12} \mathrm{Mg}_{17}, \mathrm{Al}_{12} \mathrm{Mg}_{17}+\mathrm{Mg}$ eutectic, dan mengalami peningkatan kekerasan pada lampiran[7].

Pengecoran dengan metode LFC pada material selain aluminium telah dilakukan oleh peneliti terdahulu. Pengaruh tekanan LFC pada material besi cor dan baja terhadap waktu pengisian pada cetakan menunjukkan bahwa tinggi rendah suhu tuang dan tekanan mempengaruhi waktu pengisian dalam cetakan coran sehingga waktu yang lebih cepat menghasilkan produk yang padat dan permukaan yang halus[8]. Porositas menjadi masalah yang sangat serius dan diamati dalam proses pengecoran, baik dengan bahan baku aluminium maupun bahan lainnya. Investigasi cacat porositas di_dalam pengecoran aluminium juga telah diteliti[9]. Dye penetrant merupakan salah satu metode untuk mengamati cacat porositas pada pengecoran. Penambahan unsur lain, seperti $\mathrm{Be}, \mathrm{Si}, \mathrm{Cu}$, dan $\mathrm{SiC}$ pada proses pengecoran aluminium dengan tujuan meningkatkan sifat fisis dan mekanik telah dilakukan[10][11].

Menurut beberapa jurnal yang disitasi tentang pengecoran, diketahui bahwa pengaruh temperatur tuang pada pengecoran dengan memanfaatkan limbah aluminium dari velg bekas perlu dikembangkan karena semakin meningkatnya jumlah limbah aluminium dari velg bekas. Part handle rem merupakan produk yang banyak dijumpai penggunaannya pada sepeda motor. Penelitian ini bertujuan mengetahui pengaruh temperatur tuang terhadap morfologi struktur mikro dan kekerasan pada bentuk produk handle rem sepeda motor dengan pengecoran LFC.

\section{METODE}

\subsection{Material}

Material yang digunakan pada penelitian adalah velg bekas yang termasuk bahan aluminium dengan paduan $\mathrm{Si}$, penambahan unsur silicon mempunyai karakteristik mampu alir, tahan terhadap retak dan lainnya [12], sebagaimana terlihat pada gambar 1 . Bahan velg bekas dilakukan pengujian komposisi menggunakan spectrometer. Adapun hasil uji komposisi kimia disajikan pada tabel 1.

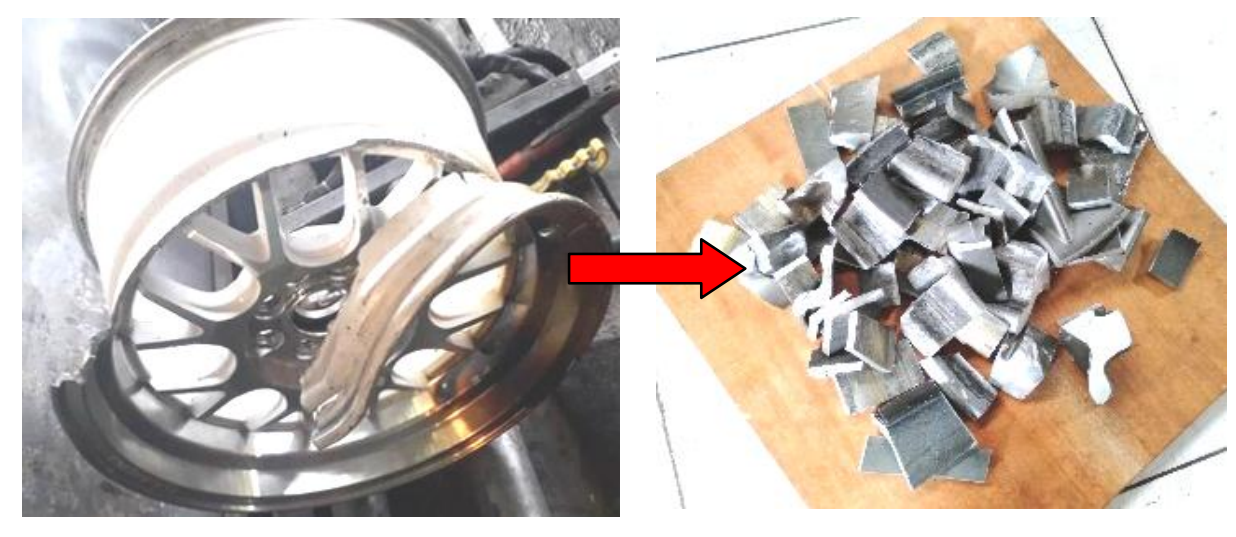

(a)

(b)

Gambar 1 (a) Velg Bekas, (b) Potongan velg 
Tabel 1 Komposisi Kimia Al-Si

\begin{tabular}{cccccccccccc}
\hline $\mathrm{Si} \%$ & $\mathrm{P} \%$ & $\mathrm{Ca} \%$ & $\mathrm{Ti} \%$ & $\mathrm{Cr} \%$ & $\mathrm{Mn} \%$ & $\mathrm{Fe} \%$ & $\mathrm{Ni} \%$ & $\mathrm{Cu} \%$ & $\mathrm{Zn} \%$ & $\mathrm{Sr} \%$ & $\mathrm{Al} \%$ \\
\hline 12.2 & 0.3 & 0.6 & 0.41 & 0.07 & 0.24 & 1.38 & 0.66 & 0.69 & 0.78 & 0.13 & $\mathrm{Bal}$ \\
\hline
\end{tabular}

Desain dan dimensi pola pengecoran handle rem disajikan pada gambar 2. Tungku krusible digunakan untuk melebur aluminium. Adapun jenis pemanas yang digunakan secara tidak langsung dengan bahan bakar gas LPG, disajikan pada gambar 3 (a). Tungku mempunyai dimensi diameter luar $400 \mathrm{~mm}$, diameter dalam $200 \mathrm{~mm}$ dan tinggi $400 \mathrm{~mm}$ dengan kapasitas peleburan $1 \mathrm{~kg}$. Pengecoran ini menggunakan pola dengan bahan dasar Styrofoam yang disajikan pada gambar 3(b).

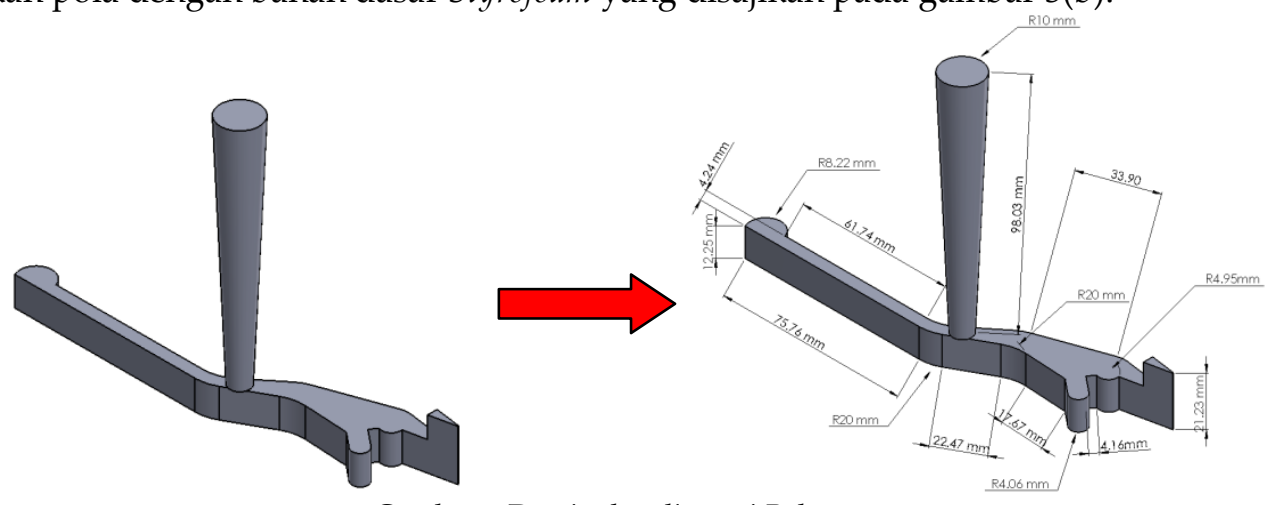

Gambar 2 Desain dan dimensi Pola coran

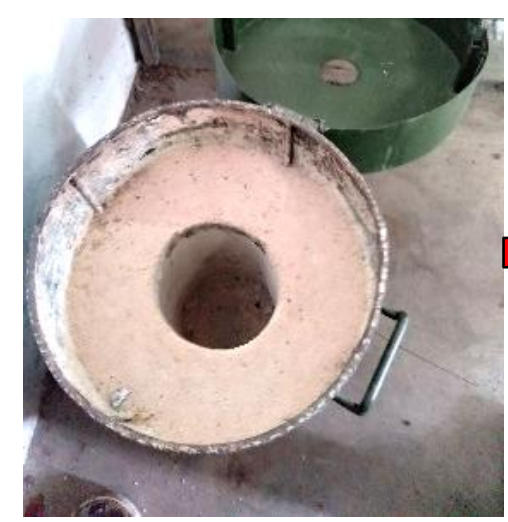

(a)

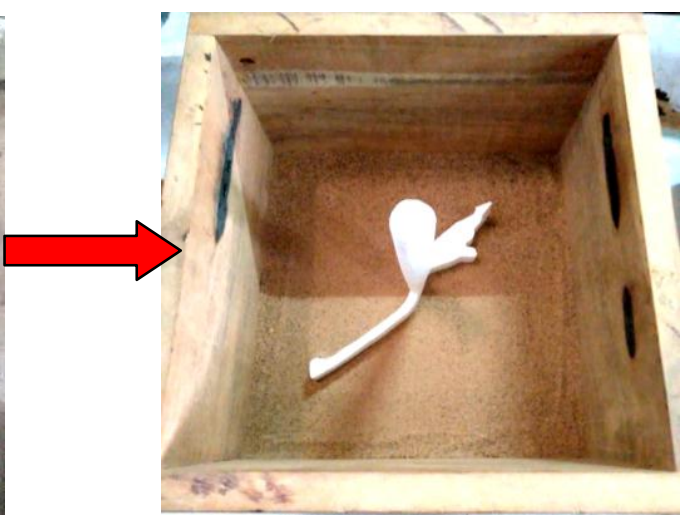

(b)

Gambar 3 (a) Tungku krusible, (b) pola handle rem dari styrofoam

\subsection{Tahapan Penelitian}

Proses pengecoran diawali dengan mempersiapkan alat dan bahan sesuai dengan kebutuhan penelitian. Kebutuhan tersebut meliputi material aluminium dari velg bekas, tungku krusible, blender, LPG, pola coran dari styrofoam, pasir silica sebagai pasir cetak pengecoran, dan infrared thermometer. Material velg bekas yang telah dipotong kecil-kecil dimasukan ke tungku pemanas sesuai dengan temperatur yang diinginkan. Parameter yang digunakan dalam penelitian adalah temperatur tuang 660, $710,760^{\circ} \mathrm{C}$ karena pada temperatur tersebut material Al sampai ke titik lebur atau melting. Ketika temperatur pengecoran sudah sesuai dengan parameter penelitian, kemudian material dituangkan pada pasir cetak dengan pola handle rem. Adapun skematik pengecoran terlihat pada gambar 4. 


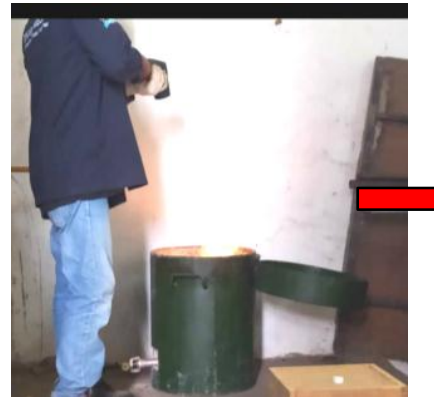

(a)

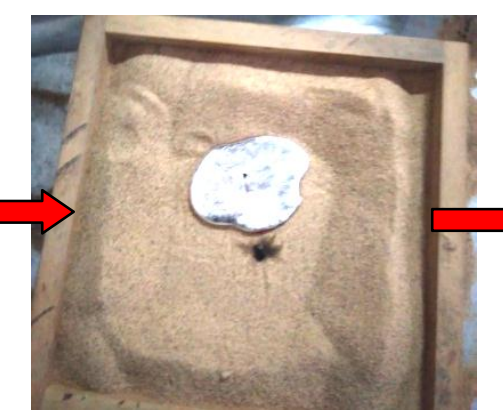

(b)

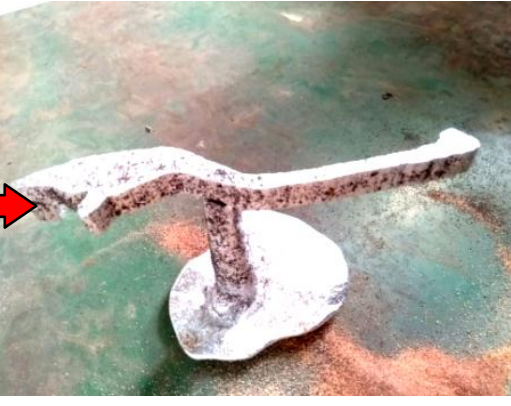

(c)

Gambar 4 Skematik pengecoran

Pengamatan morfologi struktur mikro dan kekerasan diambil perpotongan hasil coran handle rem pada tiga bagian, yaitu bagian ujung, tengah, dan pangkal dengan dimensi $10 \times 10 \mathrm{~mm}$ yang disajikan pada gambar 5. Sampel struktur mikro di-mounting menggunakan resin dan dihaluskan dengan amplas berukuran 120, 220, 400, 800, 1000, 1500, dan 2000. Etching pada sampel menggunakan ASTM E407-07 no. 3 yaitu $2 \mathrm{~mL} \mathrm{HF}, 5 \mathrm{~mL} \mathrm{HNO}$, $3 \mathrm{~mL} \mathrm{HCL}$, dan $190 \mathrm{~mL}$ aquades[13], kemudian dilakukan pengamatan makro dan mikro.

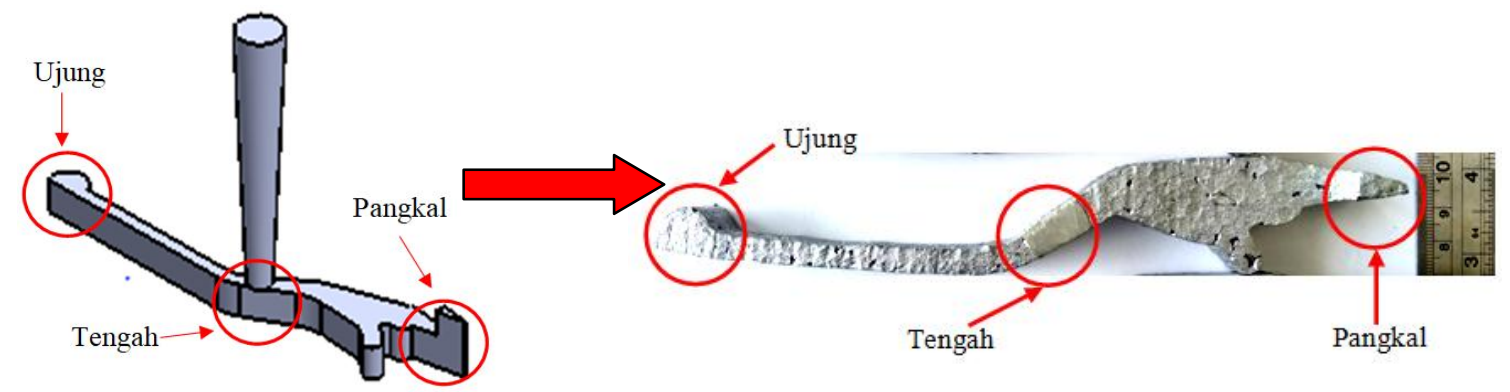

Gambar 5 Daerah pengujian

\subsection{Metode Pengukuran Secondary Dendrite Arm Spacing (SDAS)}

Pengukuran Secondary Dendrite Arm Spacing (SDAS) menggunakan metallography optic dengan 200 kali pembesaran. Analisis gambar mengunakan perangkat lunak ImageJ untuk mendapatkan rata-rata SDAS. Skematik metode pengukuran SDAS menggunakan 5 metode, tetapi pada penelitian ini menggunakan metode D. Pengukuran SDAS diambil sebanyak 5 dendrite dalam setiap foto, contoh pengukuran SDAS seperti yang ditunjukkan pada gambar 6. Dalam pengukuran SDAS menggunakan metode $\mathrm{D}, \mathrm{L}$ diukur sebagai panjang yang sejajar dengan lengan utama yang memanjang ke pusat sekunder dan $\mathrm{N}$ mewakili jumlah lengan sekunder yang dihitung satu sisi lengan utama, maka perhitungannya menggunakan persamaan 1 .

$$
\text { SDAS }=\frac{L}{N-1}
$$

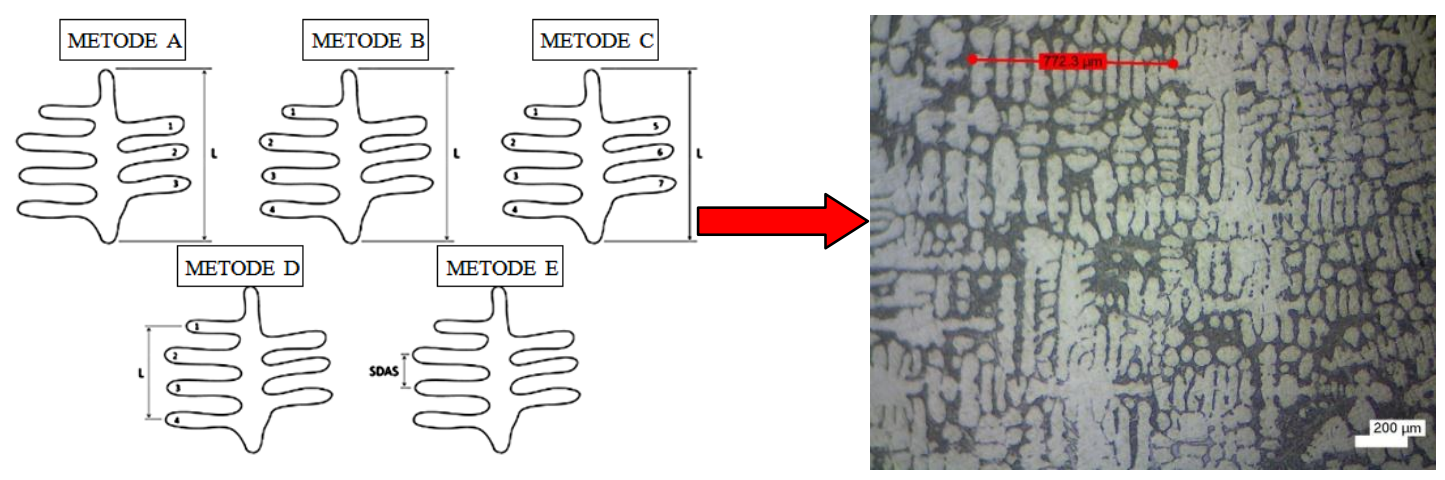

Gambar 6 Skematik SDAS[14] 
Kristal aluminium yang padat terbentuk seperti kepingan salju. Kristal diamati menggunakan metallography dan kristal tersebut berbentuk menyerupai seperti pohon sehingga disebut dendrite. Dendrite pertama kali diamati dengan memoles logam yang telah dietsa[15].

\section{HASIL DAN PEMBAHASAN}

\subsection{Hasil pengecoran secara makro}

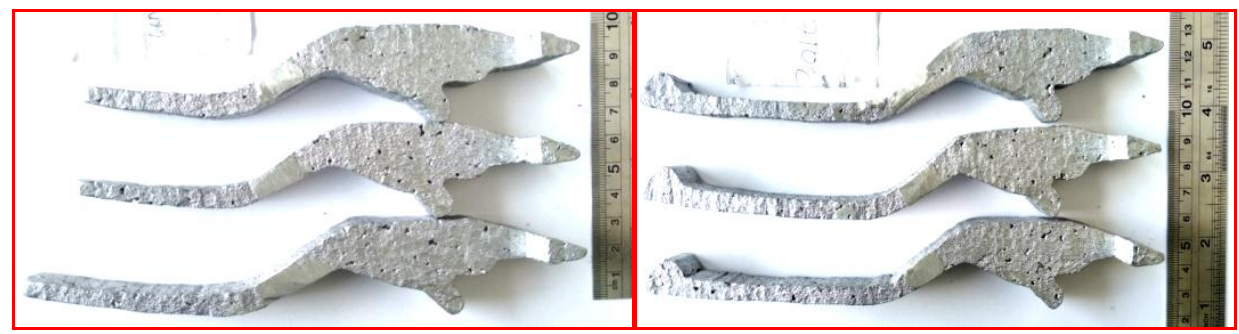

(a)

(b)

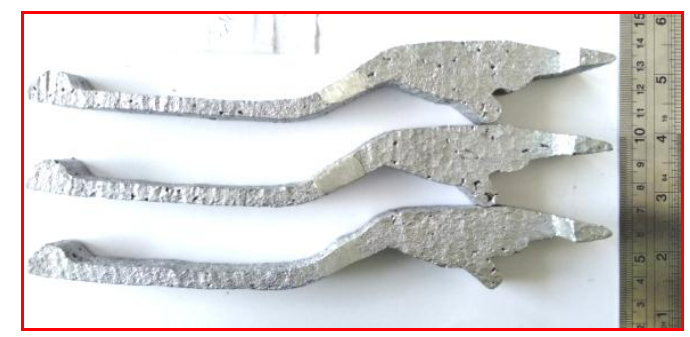

(c)

Gambar 7 Hasil pengecoran temperature tuang, (a) $660^{\circ} \mathrm{C}$ (b) $710^{\circ} \mathrm{C}$ (c) $760^{\circ} \mathrm{C}$

Hasil pengecoran dengan pola handle rem disajikan pada gambar 6. Pada temperatur tuang $660{ }^{\circ} \mathrm{C}$ hasil pengecoran tidak sempurna. Hal tersebut terjadi karena cairan logam tidak mampu mengisi seluruh pola, ditunjukkan pada gambar 7(a). Desain dan jarak saluran masuk pada pola pengecoran juga menjadi sebab sehingga logam cair sudah mencapai titik beku sebelum mengisi seluruh pola[6]. Hasil pengukuran jarak dari saluran masuk sampai pada ujung spesimen yang terisi berturut-turut $7,5 \mathrm{~cm}, 6$ $\mathrm{cm}$, dan $5,8 \mathrm{~cm}$ rata-rata dari jarak saluran masuk penuangan sampai ujung sepanjang $6,3 \mathrm{~cm}$. Pada pengecoran temperatur tuang 710 dan $760^{\circ} \mathrm{C}$ terlihat sempurna karena cairan logam memenuhi seluruh pola. Secara makro, bentuk produk mengikuti struktur pola styrofoam, sebagaimana ditunjukkan pada gambar $7(b, c)$. Temperatur penuangan pada saat proses pengecoran sangat berpengaruh terhadap hasil coran. Semakin tinggi temperatur penuangan, viskositas menjadi rendah sehingga laju pengisian logam cair cepat[8].

\subsection{Struktur mikro}

Pengujian metallography dilakukan untuk pengamatan struktur mikro daerah pangkal, tengah, dan ujung pada hasil coran daur ulang aluminium pola styrofoam dengan beberapa variasi temperatur tuang 660,710 dan $760^{\circ} \mathrm{C}$. Gambar 8 menunjukkan hasil struktur mikro yang berwarna putih adalah matrik Al dan gelap merupakan eutectic Si[16]. Parameter temperatur tuang $660^{\circ} \mathrm{C}$ menghasilkan Secondary Dendritic Arm Spacing(SDAS) Struktur eutectic Si paling halus dan rapat yang terjadi pada daerah ujung material, tetapi penyebarannya kurang merata dan terlihat adanya aglomerasi eutectic Si yang cukup banyak yang disajikan pada gambar $8(\mathrm{c})$. 


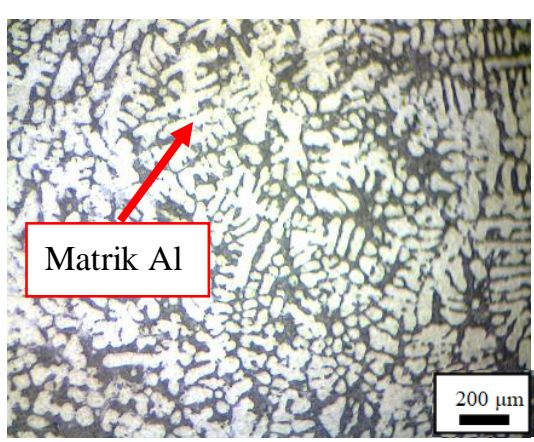

(a)

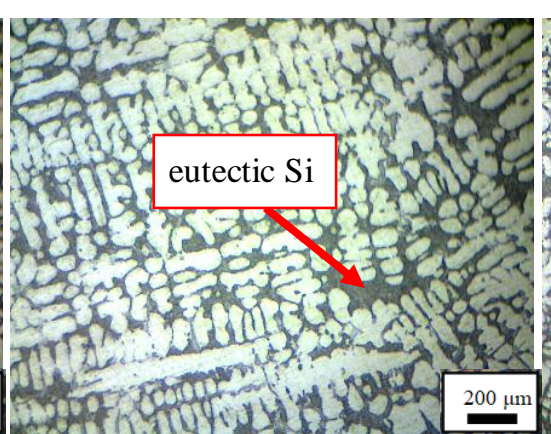

(b)

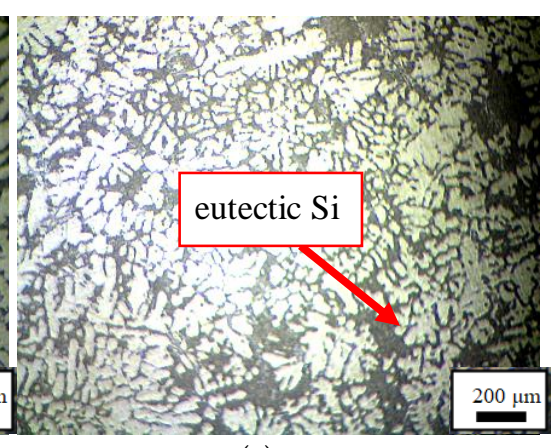

(c)

Gambar 8 Struktur mikro handle rem temperature tuang $660^{\circ} \mathrm{C}$ (a) pangkal (b) tengah (c) ujung

Investigasi struktur mikro pada temperatur taung $710^{\circ} \mathrm{C}$ yang ditunjukkan pada gambar 9, menunjukkan SDAS eutectic Si mengalami peningkatan atau lebih kasar dibandingkan hasil struktur pada temperatur tuang $660^{\circ} \mathrm{C}$. Peningkatan SDAS eutectic Si terjadi karena peningkatan temperatur tuang pada saat proses pengecoran[17][14]. Peningkatan SDAS eutectic Si terjadi pada seluruh daerah material, seperti pangkal, tengah, dan ujung dan aglomerasi eutectic Si pada semua daerah tersebut sedikit.

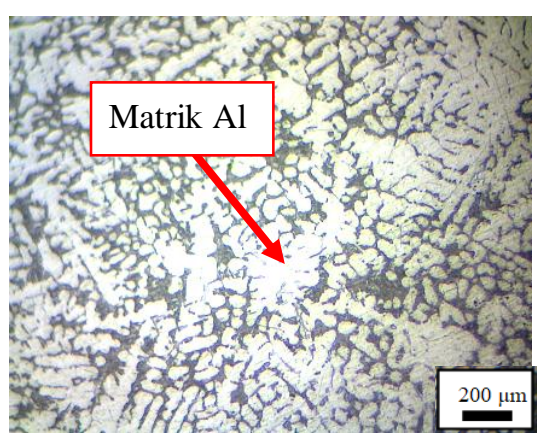

(a)

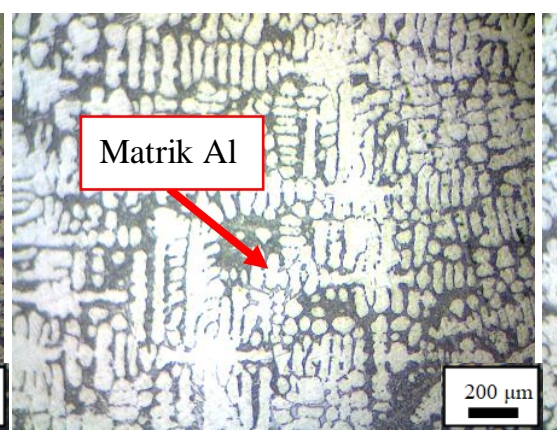

(b)

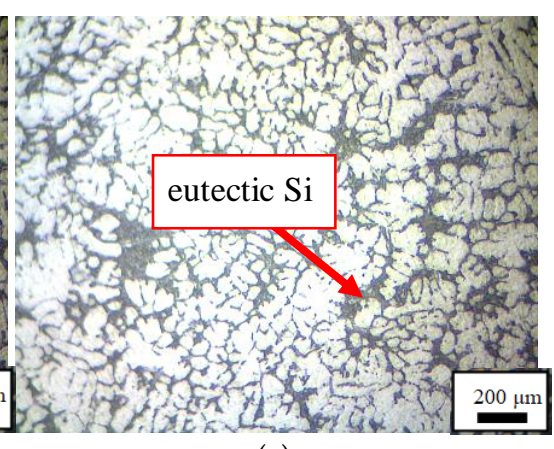

(c)

Gambar 9 Struktur mikro handle rem temperature tuang $710^{\circ} \mathrm{C}$ (a) pangkal (b) tengah (c) ujung

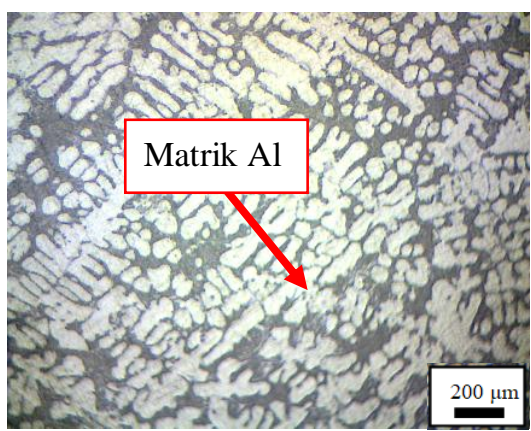

(a)

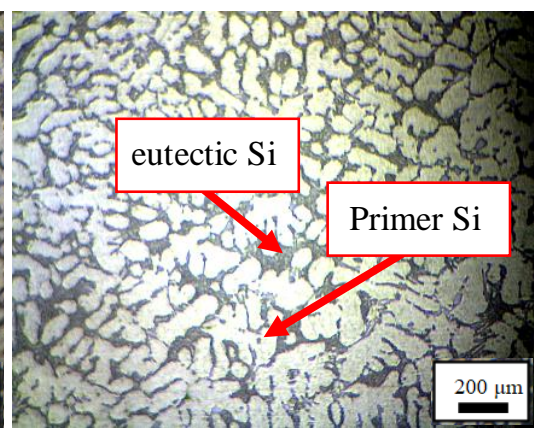

(b)

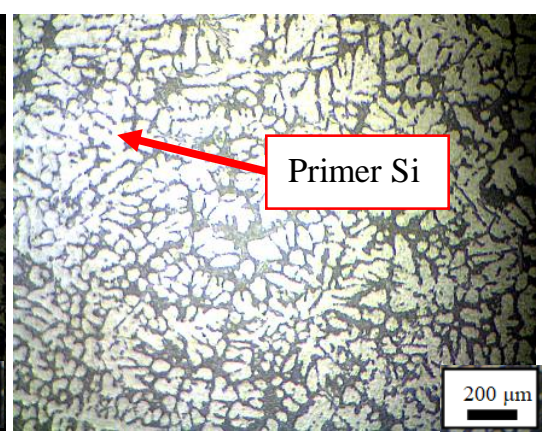

(c)

Gambar 10 Struktur mikro handle rem temperatur tuang $760^{\circ} \mathrm{C}$ (a) pangkal (b) tengah (c) ujung

Gambar 10 merupakan struktur mikro pada parameter tuang $760^{\circ} \mathrm{C}$ yang menunjukkan peningkatan SDAS eutectic Si. Akan tetapi, peningkatan tersebut tidak signifikan dibandingkan pada hasil struktur dengan temperatur tuang $710^{\circ} \mathrm{C}$. Struktur eutectic $\mathrm{Si}$ pada daerah ujung terlihat seperti serpihan jarum dan terdistribusi merata. Struktur matrik Al yang dihasilkan pada parameter tersebut terlihat lebih seragam. Hal tersebut terjadi karena cairan logam mampu mengisi pola pengecoran secara sempurna[18]. Temperatur tuang yang tinggi menyebabkan bertambahnya waktu pembekuan dan daerah tumbuh fasa silikon berubah dari serpihan menjadi globular dan silikon primer kecil menjadi silikon primer besar.

\subsection{Pengukuran Secondary Dendrite Arm Spacing (SDAS)}

Metode analisis Secondary Dendrite Arm Spacing (SDAS) dilakukan mengacu pada gambar 6 dengan menggunakan metode D[17]. Masing - masing foto diambil sebanyak 5 dendrite. Analisis ini bertujuan menghubungan hasil struktur mikro dengan sifat mekanis pada hasil coran. Pada penelitian ini SDAS 
sebanding dengan struktur mikro yang ditunjukkan pada gambar 8, 9, 10. Adapun hasil pengukuran SDAS disajikan pada tabel 2.

Tabel 2. Secondary Dendrite Arm Spacing (SDAS)

\begin{tabular}{ccccccc}
\hline \multirow{2}{*}{ Suhu Tuang $\left({ }^{\circ} \mathrm{C}\right)$} & \multicolumn{5}{c}{ Daerah spesimen } \\
\cline { 2 - 7 } & Pangkal $(\mu \mathrm{m})$ & stdev & Tengah $(\mu \mathrm{m})$ & stdev & Ujung $(\mu \mathrm{m})$ & stdev \\
\hline $\mathbf{6 6 0}$ & 332.3 & 0.67 & 548.5 & 1.58 & 310 & 3.16 \\
$\mathbf{7 1 0}$ & 439.9 & 1.58 & 783.6 & 2.54 & 425.8 & 2.54 \\
$\mathbf{7 6 0}$ & 607.5 & 2.83 & 856.1 & 1.58 & 580.7 & 3.53 \\
\hline
\end{tabular}

Hasil pengkuran SDAS menunjukkan bahwa nilai terbesar terjadi di daerah tengah spesimen pada temperatur tuang $760^{\circ} \mathrm{C}$ dengan nilai $856.1 \mu \mathrm{m}$. Pengukuran standar deviasi yang kecil menunjukkan kehomogenan SDAS. Peningkatan SDAS terjadi seiring dengan meningkatannya temperatur tuang pada saat pengecoran berlangsung[14][17]. Peningkatan temperatur tuang mengakibatkan waktu pembekuan semakin lama[19]. Fenomena peningkatan SDAS tidak hanya terjadi pada daerah tengah, tetapi juga terjadi pada daerah pangkal dan ujung spesimen.

\subsection{Kekerasan}

Pengujian kekerasan pada handle dan produk coran pada temperatur tuang 660,710 dan $760^{\circ} \mathrm{C}$ yang terlihat tabel 2 dan gambar 10. Produk handle yang ada di pasaran atau original mempunyai nilai kekerasan 110,38 BHN bagian pangkal, 110,21 BHN tengah dan 104,45 BHN ujung. Produk coran dari bahan material daur ulang pada suhu temperatur tuang $660^{\circ} \mathrm{C}$ mempunyai nilai kekerasan yang paling rendah sebesar 78,75 BHN bagian pangkal, 79,69 BHN bagian tengah, dan 79,19 BHN bagian ujung. Pengecoran dengan temperatur tuang $710^{\circ} \mathrm{C}$ memiliki nilai kekerasan 79,02 $\mathrm{BHN}$ bagian pangkal, 80,31 BHN bagian tengah, dan bagian $79,9 \mathrm{BHN}$ ujung. Pengecoran dengan temperatur tuang $760^{\circ} \mathrm{C}$ mendapatkan nilai kekerasan yang paling tinggi sebesar 81,52 BHN bagian pangkal, 82,28 BHN bagian tengah, dan 81,74 BHN bagian ujung. Nilai kekerasan pada bagian pangkal pada semua variasi suhu tuang relatif rendah dibandingkan dengan bagian ujung, dan untuk bagian tengah produk cor mendapatkan hasil nilai kekerasan yang paling tinggi. Hal tersebut terjadi karena pada bagian tengah mengalami penekanan secara gravitasi paling besar. Hasil data pengujian menunjukkan bahwa produk pengecoran mempunyai nilai kekerasan di bawah produk handle yang beredar di pasaran karena adanya kemungkinan perbedaan bahan material dan metode pengecoran.

Tabel 3. Pengujian kekerasan Brinell

\begin{tabular}{|c|c|c|c|c|c|c|c|}
\hline \multirow{2}{*}{$\begin{array}{l}\text { Suhu } \\
\text { Tuang }\end{array}$} & \multirow{2}{*}{$\begin{array}{c}\text { Bagian } \\
\text { Spesimen }\end{array}$} & \multicolumn{5}{|c|}{ Hasil Pengukuran d (mm) } & \multirow{2}{*}{ BHN } \\
\hline & & 1 & 2 & 3 & 4 & 5 & \\
\hline \multirow{3}{*}{ Original } & Pangkal & 1,03055 & 1,0425 & 1,0611 & 1,0764 & 1,0374 & 110,38 \\
\hline & Tengah & 1,04075 & 1,0628 & 1,0713 & 1,04415 & 1,03225 & 110,21 \\
\hline & Ujung & 1,06795 & 1,08665 & 1,09245 & 1,0798 & 1,0594 & 104,45 \\
\hline \multirow{3}{*}{$660^{\circ} \mathrm{C}$} & Pangkal & 1,2292 & 1,22415 & 1,24915 & 1,22405 & 1,22395 & 78,75 \\
\hline & Tengah & 1,2256 & 1,2207 & 1,224 & 1,22365 & 1,2222 & 79,69 \\
\hline & Ujung & 1,22415 & 1,22415 & 1,2292 & 1,2292 & 1,22385 & 79,19 \\
\hline \multirow{3}{*}{$710^{\circ} \mathrm{C}$} & Pangkal & 1,2326 & 1,2343 & 1,2258 & 1,21735 & 1,2308 & 79,02 \\
\hline & Tengah & 1,22585 & 1,2275 & 1,2258 & 1,21565 & 1,20005 & 80,31 \\
\hline & Ujung & 1,2411 & 1,2241 & 1,2187 & 1,2241 & 1,21225 & 79,9 \\
\hline \multirow{3}{*}{$760^{\circ} \mathrm{C}$} & Pangkal & 1,204 & 1,22295 & 1,21425 & 1,20715 & 1,20375 & 81,52 \\
\hline & Tengah & 1,20205 & 1,207 & 1,20885 & 1,20205 & 1,20545 & 82,28 \\
\hline & Ujung & 1,20565 & 1,20895 & 1,2109 & 1,211 & 1,2075 & 81,74 \\
\hline
\end{tabular}




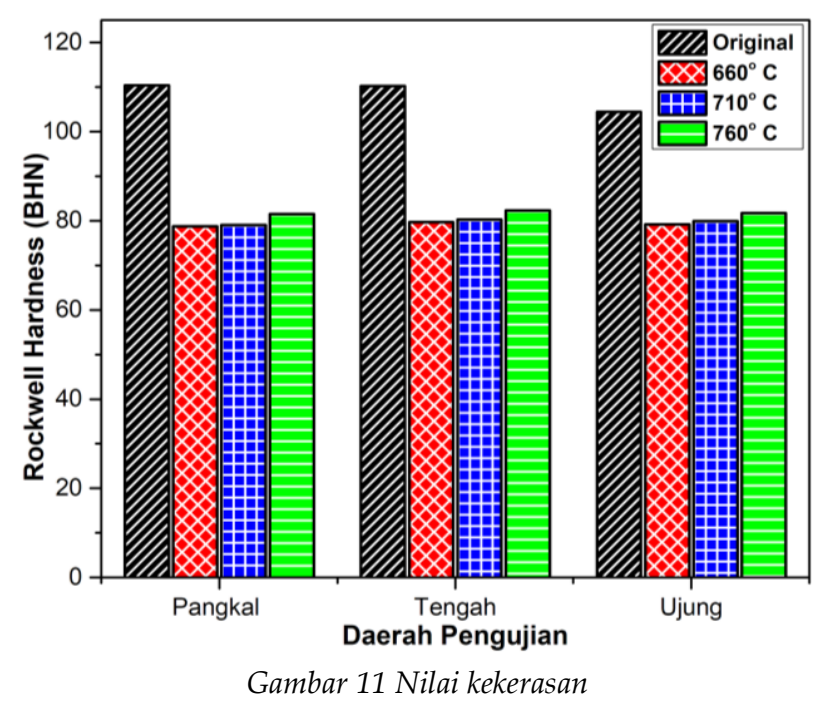

Nilai kekerasan produk cor pada setiap bagian pangkal, tengah, dan bagian ujung dari semua variasi suhu tuang mengalami peningkatan bersamaan dengan naiknya temperatur tuang pengecoran[20]. Fenomena ini terkait dengan struktur mikro yang jarak dendrit bergerombol atau halus memiliki nilai kekerasan yang rendah, sedangkan susunan jarak dendrite struktur mikro yang semakin besar atau kasar mempunyai nilai kekerasan yang tinggi. Hasil kekerasan pada penelitian diperkuat dengan hasil struktur mikro dan hasil pengukuran SDAS.

Pengecoran handle rem ini tidak ditujukan untuk studi kasus yang mengalami tumbukan atau benturan, tetapi fungsi handle rem tersebut sebatas berperan untuk mengontrol pengereman tangan serta tidak mengalami gesekan dan pembebanan yang besar. Oleh karena itu, handle rem tidak membutuhkan kekuatan dan kekerasan yang tinggi karena nilai kekerasan yang tinggi menunjukkan kegetasan material yang tinggi. Hasil produk pengecoran handle rem pada temperatur tuang $710^{\circ} \mathrm{C}$ dan $760^{\circ} \mathrm{C}$ layak dan mampu digunakan sebagaimana fungsi handle rem sepeda motor.

\section{KESIMPULAN}

Pengaruh variasi temperatur tuang pengecoran daur ulang Al-Si pola Styrofoam pada penelitian ini adalah foto makro hasil coran terbaik yang terjadi pada temperatur tuang $760^{\circ} \mathrm{C}$. Hal tersebut terjadi karena logam cair bisa mengisi keseluruh pola handle rem dengan waktu beku cukup lama. Morfologi struktur mikro menunjukkan semakin tinggi temperatur mengakibatkan SDAS semakin kasar. Hal tersebut terjadi pada temperatur tuang $760^{\circ} \mathrm{C}$. Nilai kekerasan tertinggi terjadi pada temperatur tuang $760^{\circ} \mathrm{C}$ bagian tengah dengan nilai $82.28 \mathrm{BHN}$ sehingga nilai kekerasan meningkat $2.59 \%$.

\section{DAFTAR PUSTAKA}

[1] K. Paramasivam, M. Vijay Anand, and M. Sambathkumar, "Investigation of optimum process parameter of lost foam casting of A356/SiC metal matrix composite," Materials Today: Proceedings., no. xxxx, 2021, doi: 10.1016/j.matpr.2021.06.035.

[2] S. Otarawanna and A. K. Dahle, "Casting of aluminium alloys," Fundamentals of Aluminium Metallurgy: Production, Processing and Applications., pp. 141-154, 2010, doi: 10.1533/9780857090256.1.141.

[3] S. Shivkumar, S. Ricci, C. Keller, and D. Apelian, "Effect of solution treatment parameters on tensile properties of cast aluminum alloys," Journal of Heat Treating., vol. 8, no. 1, pp. 63-70, 1990, doi: 10.1007/BF02833067.

[4] F. Ettemeyer et al., "Characterisation of the decoring behaviour of inorganically bound cast-in sand cores for light metal casting," Journal of Materials Processing Technology., vol. 296, no. October 2020, 2021, doi: 10.1016/j.jmatprotec.2021.117201.

[5] J. Baasch, L. Windisch, F. Koch, S. Linke, E. Stoll, and C. Schilde, "Regolith as substitute mold material for aluminum casting on the Moon," Acta Astronautica., vol. 182, no. September 2020, pp. 1- 
12, 2021, doi: 10.1016/j.actaastro.2021.01.045.

[6] M. Karimian, A. Ourdjini, M. H. Idris, and H. Jafari, "Effects of Casting Parameters on Shape Replication and Surface Roughness of LM6 Aluminium Alloy Cast Using Lost Foam Process," Transactions of the Indian Institute of Metals., vol. 68, no. 2, pp. 211-217, 2015, doi: 10.1007/s12666-0140446-z.

[7] S. M. Emami, M. Divandari, E. Hajjari, and H. Arabi, "Comparison between conventional and lost foam compound casting of $\mathrm{Al} / \mathrm{Mg}$ light metals," International Journal of Cast Metals Research., vol. 26, no. 1, pp. 43-50, 2013, doi: 10.1179/1743133612Y.0000000037.

[8] M. Khodai and N. Parvin, "Pressure measurement and some observation in lost foam casting," Journal of Materials Processing Technology., vol. 206, no. 1-3, pp. 1-6, 2008, doi: 10.1016/j.jmatprotec.2007.11.309.

[9] S. Mozammil, J. Karloopia, and P. K. Jha, "Investigation of porosity in Al casting," Materials Today: Proceedings., vol. 5, no. 9, pp. 17270-17276, 2018, doi: 10.1016/j.matpr.2018.04.138.

[10] P. S. Wang, S. L. Lee, J. C. Lin, and M. Ten Jahn, "Effects of solution temperature on mechanical properties of 319.0 aluminum casting alloys containing trace beryllium," Journal of Materials Research., vol. 15, no. 9, pp. 2027-2035, 2000, doi: 10.1557/JMR.2000.0291.

[11] S. Sivananthan, K. Ravi, and S. J. Samuel, "Effect of SiC particles reinforcement on mechanical properties of aluminium 6061 alloy processed using stir casting route," Materials Today: Proceedings., vol. 21, pp. 968-970, 2020, doi: 10.1016/j.matpr.2019.09.068.

[12] H. Zhan and B. Hu, "Analyzing the microstructural evolution and hardening response of an Al-SiMg casting alloy with Cr addition," Materials Characterization., vol. 142, no. May, pp. 602-612, 2018, doi: 10.1016/j.matchar.2018.06.026.

[13] ASTM standard 407-07, "ASTM 407-07, Standard Practice for Microetching Metals and Alloys, ASTM International, West Conshohocken, PA, 2007," pp. 1-21, 2005, doi: 10.1520/E0407-07.2.

[14] E. Vandersluis and C. Ravindran, "Comparison of Measurement Methods for Secondary Dendrite Arm Spacing," Metallography, Microstructure, and Analysis., vol. 6, no. 1, pp. 89-94, 2017, doi: 10.1007/s13632-016-0331-8.

[15] G. K. Sigworth, "Fundamentals of solidification in aluminum castings," International Journal of Metalcasting., vol. 8, no. 1, pp. 7-20, 2014, doi: 10.1007/BF03355567.

[16] H. Cao et al., "Effect of vacuum degree and T6 treatment on the microstructure and mechanical properties of Al-Si-Cu alloy die castings," Vacuum, vol. 172, no. October 2019, 2020, doi: 10.1016/j.vacuum.2019.109063.

[17] V. A. Aranda, I. A. Figueroa, G. González, J. A. García-Hinojosa, and I. Alfonso, "Study of the microstructure and mechanical properties of Al-Si-Fe with additions of chromium by suction casting," Journal of Alloys and Compounds., vol. 853, 2021, doi: 10.1016/j.jallcom.2020.157155.

[18] V. Dao, S. Zhao, W. Lin, and C. Zhang, "Effect of process parameters on microstructure and mechanical properties in AlSi9Mg connecting-rod fabricated by semi-solid squeeze casting," Materials Science and Engineering. A, vol. 558, pp. 95-102, 2012, doi: 10.1016/j.msea.2012.07.084.

[19] S. B. Bin, S. M. Xing, L. M. Tian, N. Zhao, and L. Li, “Influence of technical parameters on strength and ductility of AlSi9Cu3 alloys in squeeze casting," [1] K. Paramasivam, M. Vijay Anand, and M. Sambathkumar, "Investigation of optimum process parameter of lost foam casting of A356/SiC metal matrix composite," Transactions of Nonferrous Metals Society of China (English Edition)., no. xxxx, 2021, doi: 10.1016/j.matpr.2021.06.035.

[20] E. J. Vinarcik, High integrity die casting processes. John Wiley \& Sons, 2002. 